\section{P1-S2.53 HEPATITIS C VIRUS IN MEN WHO HAVE SEX WITH MEN WITH NO HISTORY OF INJECTION DRUG USE - EVIDENCE FOR SEXUAL TRANSMISSION? A CANADIAN PERSPECTIVE}

doi:10.1136/sextrans-2011-050108.110

${ }^{1} \mathrm{~S}$ Totten, ${ }^{1} \mathrm{M}$ McGuire, ${ }^{2} \mathrm{~J}$ Cox, ${ }^{2} \mathrm{G}$ Lambert, ${ }^{3} \mathrm{M}$ Fyfe, ${ }^{4} \mathrm{~W}$ Husbands, ${ }^{5} \mathrm{~T}$ Myers, ${ }^{5} \mathrm{R}$ Remis, ${ }^{6} \mathrm{~J}$ Wylie, ${ }^{1} \mathrm{~T}$ Wong. ${ }^{1}$ Public Health Agency of Canada, Ottawa, Canada; ${ }^{2}$ Direction de la santé publique de Montréal, Institut national de santé publique du Québec, Montreal, Canada; ${ }^{3}$ Vancouver Island Health Authority, Victoria, Canada; ${ }^{4}$ AIDS Committee of Toronto, Toronto, Canada; ${ }^{5}$ University of Toronto, Toronto, Canada; ${ }^{6}$ Cadham Provincial Public Health Laboratory, Winnipeg, Canada

Background Sexual transmission of hepatitis $\mathrm{C}$ virus (HCV) is not common compared to other modes of transmission such as injection drug use (IDU). There have been recent reports of sexually transmitted HCV outbreaks among men who have sex with men (MSM) in Europe. The present analysis examines the Canadian HCV seroprevalence in MSM with no reported history of IDU. Methods Data from Phase 1 of M-Track (2005-2007), a national enhanced surveillance system of HIV and other sexually transmitted and blood-borne infections (STBBI) and associated risk behaviours among MSM in Canada, were analysed. HCV and HIV status were ascertained using serology tests on dried blood spot (DBS) specimens, and risk factors were assessed via self-administered questionnaire. Bivariate analyses using $\chi 2$ tests and ORs with 95\% CIs were performed.

Results Overall (regardless of IDU history), 5.3\% of M-Track participants were seropositive for HCV. Among MSM who did not report any history of IDU ( $\mathrm{N}=3250)$, HCV seropositivity was $2.1 \%$, and was higher among HIV-infected MSM compared to those who were uninfected $(5.1 \%$ vs $1.7 \%$ respectively, $p<0.001)$. Factors associated with HCV seropositivity among non-IDU are presented in Abstract P1-S2.53 table 1. Being 30 yearss of age or older, having ever received money, drugs, or goods for sex, and use of any recreational drug in the $2 \mathrm{~h}$ preceding or during sex (specifically

Asbtract P1-S2.53 Table 1 Self-reported factors associated with HCV seropositivity among MSM with no self-reported history of IDU, M-Track Phase 1 (2005-2007)

\begin{tabular}{|c|c|c|c|c|}
\hline Risk factor & & $\begin{array}{l}\text { HCV positive } \\
\text { N }(\%)\end{array}$ & $\begin{array}{l}\text { Univariate } \\
\text { OR (95\% CI) }\end{array}$ & $p$ value \\
\hline \multirow[t]{2}{*}{ Age $(\mathrm{N}=2167)$} & 29 or less (Ref) & $2(0.4)$ & \multirow[t]{2}{*}{5.5 (1.3 to 22.8$)$} & \multirow[t]{2}{*}{0.015} \\
\hline & 30 and up & $38(2.2)$ & & \\
\hline \multirow{2}{*}{$\begin{array}{l}\text { Number of male anal sex } \\
\text { partners in past } 6 \text { months } \\
(\mathrm{N}=1342)\end{array}$} & One (Ref) & $5(1.1)$ & \multirow[t]{2}{*}{1.5 (0.6 to 4.2$)$} & \multirow[t]{2}{*}{0.408} \\
\hline & Two or more & $15(1.7)$ & & \\
\hline \multirow{2}{*}{$\begin{array}{l}\text { HIV seroconcordant unprotected } \\
\text { anal intercourse ("serosorting") } \\
\text { ( } \mathrm{N}=2136)\end{array}$} & No (Ref) & $30(1.9)$ & \multirow[t]{2}{*}{$0.6(0.3$ to 1.5$)$} & \multirow[t]{2}{*}{0.266} \\
\hline & Yes & $6(1.1)$ & & \\
\hline \multirow{2}{*}{$\begin{array}{l}\text { Ever received money, goods, } \\
\text { or drugs for sex }(N=2534)\end{array}$} & No (Ref) & $30(1.3)$ & \multirow[t]{2}{*}{$8.2(4.6$ to 14.5$)$} & \multirow[t]{2}{*}{$<0.001$} \\
\hline & Yes & $21(9.7)$ & & \\
\hline \multirow{2}{*}{$\begin{array}{l}\text { Ever used recreational drugs } \\
\text { within } 2 \mathrm{~h} \text { of } \operatorname{sex}(\mathrm{N}=2536)\end{array}$} & No (Ref)Yes & $32(1.6)$ & \multirow[t]{2}{*}{$2.2(1.2$ to 4.0$)$} & \multirow[t]{2}{*}{0.008} \\
\hline & & $17(3.4)$ & & \\
\hline \multirow{2}{*}{$\begin{array}{l}\text { Ever used heroin/opioids } \\
\text { within } 2 \mathrm{~h} \text { of } \operatorname{sex}(N=2521)\end{array}$} & No (Ref) & $42(1.7)$ & \multirow[t]{2}{*}{8.5 (3.2 to 22.9$)$} & \multirow[t]{2}{*}{$<0.001$} \\
\hline & Yes & $5(12.8)$ & & \\
\hline \multirow{2}{*}{$\begin{array}{l}\text { Ever used alcohol within } \\
2 \mathrm{~h} \text { of } \operatorname{sex}(\mathrm{N}=2575)\end{array}$} & No (Ref) & $14(2.1)$ & \multirow[t]{2}{*}{$0.9(0.5$ to 1.7$)$} & \multirow[t]{2}{*}{0.729} \\
\hline & Yes & $35(1.8)$ & & \\
\hline \multirow{2}{*}{$\begin{array}{l}\text { Ever used marijuana within } \\
2 \mathrm{~h} \text { of } \operatorname{sex}(\mathrm{N}=2539)\end{array}$} & No (Ref) & $19(1.2)$ & \multirow[t]{2}{*}{$2.8(1.6$ to 5.1$)$} & \multirow[t]{2}{*}{$<0.001$} \\
\hline & Yes & $31(3.3)$ & & \\
\hline \multirow{2}{*}{$\begin{array}{l}\text { Ever used tranquilisers within } \\
2 \mathrm{~h} \text { of } \operatorname{sex}(\mathrm{N}=2518)\end{array}$} & No (Ref) & $46(1.9)$ & \multirow[t]{2}{*}{5.5 (1.6 to 18.7$)$} & \multirow[t]{2}{*}{0.016} \\
\hline & Yes & $3(9.4)$ & & \\
\hline \multirow{2}{*}{$\begin{array}{l}\text { Ever used cocaine within } \\
2 \mathrm{~h} \text { of } \operatorname{sex}(\mathrm{N}=2520)\end{array}$} & No (Ref) & $29(1.4)$ & \multirow[t]{2}{*}{4.1 (2.3 to 7.3$)$} & \multirow[t]{2}{*}{$<0.001$} \\
\hline & Yes & $20(5.3)$ & & \\
\hline \multirow{2}{*}{$\begin{array}{l}\text { Ever used sexual enhancers } \\
\text { within } 2 \mathrm{~h} \text { of } \operatorname{sex}(N=2545)\end{array}$} & No (Ref) & $29(1.8)$ & \multirow[t]{2}{*}{$1.1(0.6$ to 2.0$)$} & \multirow[t]{2}{*}{0.671} \\
\hline & Yes & $19(2.0)$ & & \\
\hline
\end{tabular}

heroin/opioids, marijuana, tranquilisers, or cocaine) were all positively associated with being seropositive for HCV.

Conclusions These findings do not confirm sexual transmission of HCV given the possibility of unreported IDU or other unknown parenteral transmission risk factors in this sample; however, they do support existing evidence of increased risk of HCV infection among HIV-infected MSM. Interpretation of results is limited by the self-reported nature of behaviours and the inability of laboratory tests used to distinguish between current infection from resolved/treated HCV or acute from chronic HCV status. Furthermore, behaviours reported in the past 6 months may not accurately reflect the risk profile of $\mathrm{HCV}$-seropositive individuals at the time of infection. HCV testing for HIV-infected MSM, even in the absence of an IDU history, may be of benefit.

\section{P1-S2.54 REPEAT GONOCOCCAL AND CHALYMADIAL INFECTIONS IN A COHORT OF MEN WHO HAVE SEX WITH MEN IN INDIA}

doi:10.1136/sextrans-2011-050108.111

${ }^{1} \mathrm{G}$ R Deshpande, ${ }^{1} \mathrm{~A}$ R Risbud, ${ }^{2} \mathrm{P}$ Narayanan, ${ }^{2} \mathrm{P}$ parimi, ${ }^{2} \mathrm{~A}$ Das. ${ }^{1}$ National AIDS Research Institute, Pune, India; ${ }^{2}$ Family Health International, New Delhi, India

Background Men who have sex with men (MSM) are found to be at increased risk for many sexually transmitted infections (STI). Among the STIs, most common are bacterial STIs such as Neisseria gonorrhoea (NG) and Chlamydia trachomatis (CT). In the present study we analysed determinants of repeat gonococcal and chlymadial infections among the cohort of high-risk MSM.

Methods Between 2008 to 2009, 512 MSM attending STI clinics in four clinics of two cities (Mumbai and Hyderabad) of India were recruited and followed for 3 months. First catch urine, rectal swabs, Pharyngeal swabs were collected in all visits and tested for NG and CT by Gen-Probe APTIMA Combo II assay and Roche PCR (Pharyngeal swabs positive by Roche Amplicor and 16s RNA NG PCR were considered). Presumptive treatment for gonorrhoea and chlamydia at the baseline visit and syndromic STI management at all subsequent visits was provided during the study period. Re-infection was defined as a positive test result occurring after 30 days and above after an initial positive result until the last follow-up.

Results Of 417 MSMs recruited during 2008-2009, 454 made at least on fallow-up visit. Three hundred and fifteen were NG infected and 138 were CT infected. 41 (9\%) NG and 7 (1.5\%) CT re-infections were observed during the follow-up visits see Abstract P1-S2.54 Table 1. Past history of STI (as reported by the participants) $(\mathrm{OR}=2.82, \mathrm{p}=0.00)$ and diagnosis of any STI by Physician $(\mathrm{OR}=2.24, \mathrm{p}=0.05)$ were significantly associated factors with re-infection.

Conclusions Cumulative incidence of repeat gonococcal infections among MSMs highlight the need of a routine STI screening, prevention counselling, promoting use of consistent condom, laboratory screening and prompt treatment of patients at high risk These efforts maximally help in avoiding recurrent NG/CT reinfection among high risk MSMs and there partners.

Abstract P1-S2.54 Table 1 Re-infection frequency among cohort of men having sex with men in India

\begin{tabular}{lrrrrr}
\hline $\begin{array}{l}\text { Visits } \\
\text { NG-Re-infection }\end{array}$ & Visit 1 & Visit 2 & Visit 3 & Visit 4 & Total \\
\hline No re-infection/ Negatives & 512 & 435 & 342 & 232 & 1521 \\
$\quad$ Re-infected (31 to 292 days) & 0 & 19 & 13 & 9 & $\mathbf{4 1}$ \\
$\quad$ Total & 512 & 454 & 355 & 241 & 1562 \\
$\begin{array}{l}\text { CT-Re-infection } \\
\text { No re-infection/Negatives }\end{array}$ & 512 & 451 & 352 & 240 & 1555 \\
Re-infected (31 to 291 days) & 0 & 3 & 3 & 1 & $\mathbf{7}$ \\
Total & 512 & 454 & 355 & 241 & 1562 \\
\hline
\end{tabular}

